
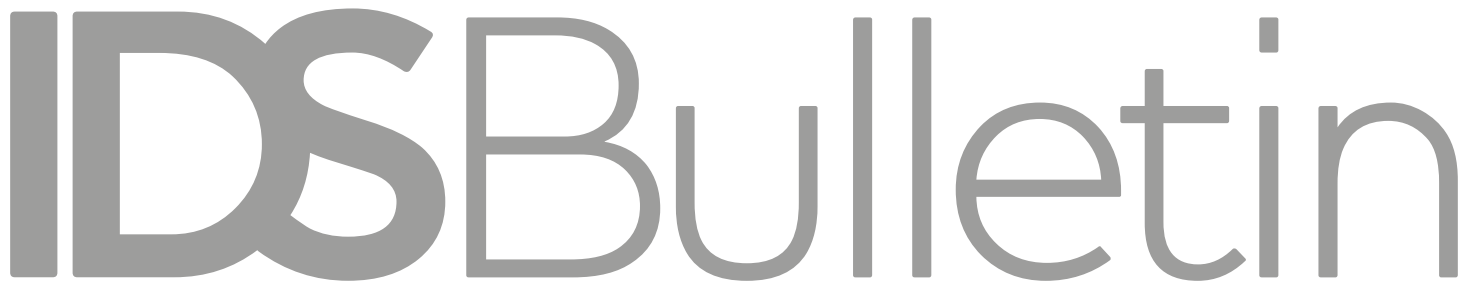

Transforming Development Knouledge Volume 47 | Number 3 | May 2016

\title{
RUPTURES AND RIPPLE EFFECTS IN THE MIDDLE EAST AND BEYOND
}

Editors Mariz Tadros and Jan Selby

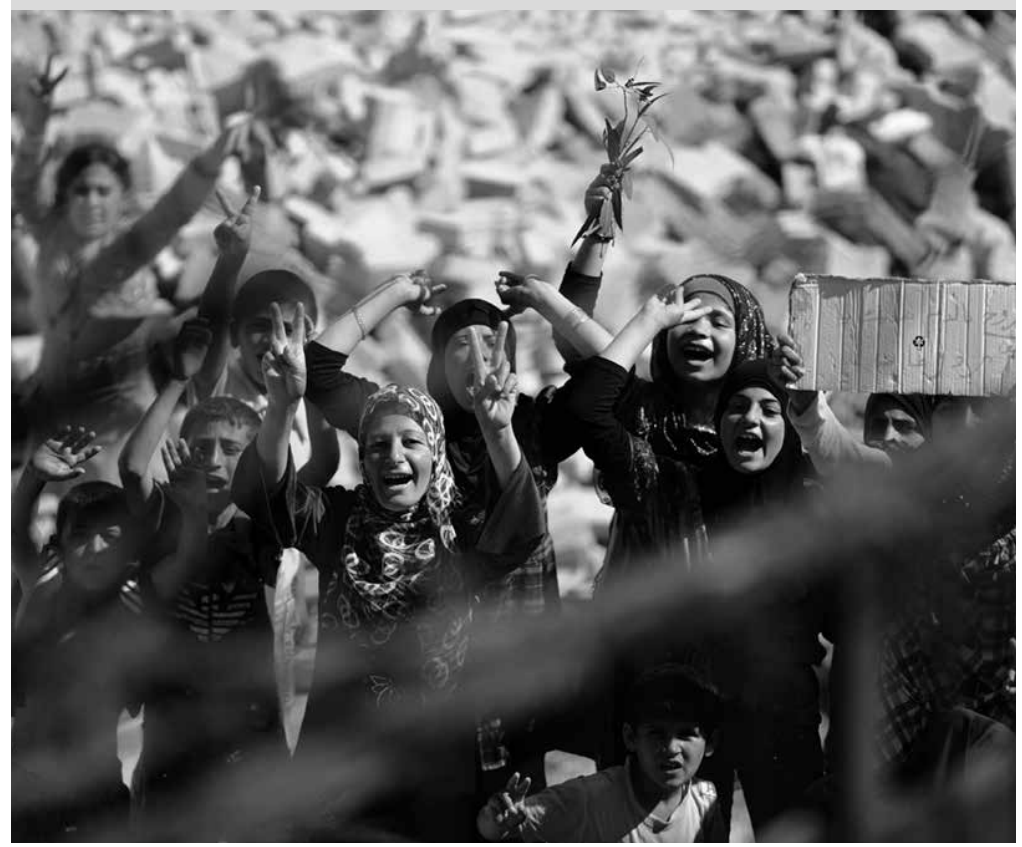


Notes on Contributors

Introduction: Eight Myths of Conflict and Development in the Middle East Jan Selby and Mariz Tadros

The Syrian Humanitarian Disaster: Disparities in Perceptions, Aspirations, and Behaviour in Jordan, Lebanon and Turkey

Dawn Chatty

Syria's Lost Generation: Refugee Education Provision and Societal Security in an Ongoing Conflict Emergency

Shelley Deane

The 'Rojava Revolution' in Syrian Kurdistan: A Model of Development for the Middle East?

Can Cemgil and Clemens Hoffmann

A Panoramic Perspective on Islamist Movements in the Middle East

Ali Bakr

Rethinking the Youth Bulge and Violence

Akram Alfy

The Political Economy of Violence in Egypt

Magdy Rezk

Glossary 


\title{
Introduction: Eight Myths of Conflict and Development in the Middle East
}

\author{
Jan Selby and Mariz Tadros
}

Abstract In this introductory article we identify eight myths of conflict and development related to the Middle East region. Some of these myths, which cut across academia, foreign policy and development interventions, are specific to the Middle East; others are 'global' myths that regional developments contradict. We do not claim to be the first to identify all these myths; many of our arguments are indebted to a long history of critical scholarship. The articles in this IDS Bulletin all speak to the disconnects, disjunctures and misconceptions highlighted here.

Perhaps more than any other region or in any period of post-Cold War history, the Middle East since the Arab Spring constitutes a significant challenge to established ideas about development and its relationship with conflict. The struggles of democracy movements, the resilience and rebirth of authoritarian regimes, the regional conflagration around Syria, new experiments with Islamism, and the return of geopolitics all, in one way or another, challenge these established ideas. The Middle East has always been something of an outlier within development thinking and practice: development policy and the discipline of development studies have always taken sub-Saharan Africa, South Asia and Latin America as their central reference points, not the Middle East. But with so much international attention currently on the Middle East, it is worthwhile examining what trends and events there tell us about development and the role of conflict therein. This is what we try to do in this article.

In what follows, we identify eight myths of conflict and development related to the Middle East region. Some of these myths are specific to the Middle East; others are 'global' myths that regional developments contradict. We do not claim to be the first to identify all these myths; many of our arguments are indebted to a long history of critical scholarship. Moreover, we should emphasise that we do not mean to suggest that these myths are adhered to all of the time: a diversity of views about development and the 'development-security nexus' of 
course exists. However, we think that these myths cut across a great deal of academia, policy and practice, and provide underpinning assumptions for development thinking and interventions, even when they are only implicit. Myth number one is a clear case in point.

\section{Myth number 1: that there is a unilinear model of development}

The idea that development is a linear process, whereby societies progress through a series of steps from 'low' to 'high' development, or from 'traditional' to 'modern' forms, is one of the hallmarks of modern development thinking. So also is the assumption that just one overall form or direction of this process exists, whatever the minor or temporary deviations from it. Such assumptions were explicit in classical early 'modernisation theory', in which, at least by Rostow's account, societies were understood to develop through five stages of economic growth, from 'tradition' to 'maturity' and 'high consumption', with different societies being at different stages of this process (Rostow 1960). Few now understand development in such explicitly unilinear terms. Nevertheless, at a more implicit level, the belief in the existence of a single linear model of development continues to underpin much development thinking and practice. It is implicit in the oft-voiced claim that there is a direct positive relationship between economic and political liberalisation - that is, in claims that economic growth, commercial interests, trade and investment interdependencies, and consumer power naturally build up pressure for democratisation. It is no less implicit in the standard modernist dictum that modernisation is associated with the decline of religion and weakening of communal and sectarian identities, as politics and identities realign around the de-secularised national state (see e.g. Berger 1999). It was assumed by the 'end of history' mentality that characterised the early post-Cold War years (Fukuyama 1992). And it is implicit, too, in the notion of 'transition', whereby 'countries in transition' are assumed to be transitioning from some abnormal to a normal liberal development path.

In reality, of course, there is no unilinear model of development: there is neither a single direction nor a single destination, nor even a single route towards it. In this broadest of senses no correlates of development exist - as the Middle East, more strikingly than any other region, makes clear. Thus, on the Arabian Peninsula, in particular, rapid economic development, urbanisation, global economic integration and, more recently, financialisation have been associated not with the withering of authoritarian regimes, but with their entrenchment. Across the Middle East - as also elsewhere - modernisation has been associated not with the weakening of religious, communal and sectarian identities, but with their consolidation and reinvention. Contra Fukuyama, no post-ideological or post-historical convergence has occurred, but rather an explosion of political projects and forces, most obviously on the Islamist side but also including, for instance, anti-capitalist and anarchist movements (Cemgil and Hoffmann, this IDS Bulletin). What we see in the contemporary Middle East, in sum, is not a region that is transitioning from tradition to modernity, but one where rapid economic and social change, and politically inspired 'revolutions of backwardness' 
(Matin 2013), have produced strikingly hybrid social and political structures, in which 'modern' and 'traditional' forms are juxtaposed, and from which the direction of future development is far from clear.

\section{Myth number 2: that low development and violent conflict are natural bedfellows}

Nothing illustrates the continuing allure of the unilinear model of development better than the widely held assumption that there is a clear correlation as well as causal relationship between low development and violent conflict. The belief in such a linkage almost goes without saying in post-Cold War development thinking and policy, and is the founding assumption of the very idea of the 'security-development nexus': that under-development is a central motor of conflict, which in turn is an obstacle to development, trapping poor societies in a vicious cycle of poverty and violence. Kofi Annan's contention that 'there can be no long-term security without development; there can be no long-term development without security' (quoted in Allouche and Lind 2013: 1); a former UK International Development Secretary's claim that 'the higher a country's GDP per capita, the lower the risk of internal war' (Mitchell 2010); Paul Collier's characterisation of war as 'development in reverse' (Collier 2003); Shimon Peres' claim that 'poverty and distress' in the Middle East' have given rise to 'fanaticism, fundamentalism and false messianism' (Peres 1993: 45-6); and Thomas Friedman's thesis that once a country has a middle class large enough to support a MacDonald's franchise, or an industrial base large enough to provide parts for his laptop computer, it will no longer go to war (Friedman 1999: 195; 2005 : ch. 12) all illustrate this line of thinking. The contemporary post-conflict 'peace-building' project does the same, its fundamental rationale and overall objective being to transform vicious cycles of under-development and conflict into virtuous cycles of peace and prosperity. The guiding premise is that all bad things go together, as do all good things.

For most of the period after the collapse of the Berlin wall, the concentration of the world's civil wars in sub-Saharan Africa at least lent the myth of security and development some superficial plausibility. Even during this period, however, it should have been evident that low development and conflict were unlikely to remain so tightly correlated. Historically, large-scale violence has been a universal and therefore arguably necessary feature of the transition to capitalist modernity, among early and later developing societies alike (Moore 1967; Cramer 2006); and historically, also, for the majority of the twentieth century nothing even close to a positive relationship between high development and peace existed. Indeed, if anything the relationship was negative, with the industrial powers of Europe, the United States (US), the Soviet Union and Japan being the leading practitioners and exporters of war.

These historical patterns alone undercut the cosy assumption that under-development and violent conflict are natural bedfellows. But the Arab Spring and its aftermath have completely blown it apart. Since 2011, large-scale civil violence has rocked Bahrain, Egypt, Iraq, Libya, 
Syria, Tunisia, Turkey, Palestine and Yemen - all, with the exception of Palestine and Yemen, being middle-income countries with largely urban and quite highly educated populations (and Palestine would fit this description too, were it a state). These conflicts, in turn, have reversed a long-term downturn in the worldwide incidence of civil war (Pettersson and Wallensteen 2015). Economic dislocation was of course an important factor behind these uprisings and ensuing violence, including impacts resulting from economic liberalisation (as in Syria: Dahi and Munif 2011; Hinnebusch 2012) and the global financial crisis of 2007-8 (Dahi 2012). But they cannot be explained by such economic factors alone, much less by 'low development': they were fundamentally political in their causes and aims, rooted in the political structures and contradictions of incumbent regimes. Regionally and globally, economic development continues apace - however disfunctionally in many states - but this is not translating into greater social or political peace. The correlation between low development and conflict has, in short, clearly been broken.

\section{Myth number 3: that there is an alternative rentier path of development}

Rentier state theory provides an important counter-argument to the above, essentially suggesting that the Middle East's modern development path, though deviating from the standard liberal model of development, has nevertheless been determined by economic forces in a quite predictable way. In the classical liberal model, growing economic productivity in society unleashes political change, as the state, fiscally reliant as it is on taxation, becomes hostage to demands for representation. In the rentier variation of this model, by contrast, the state has a high degree of fiscal autonomy from society, courtesy of its access to international rents - whether from hydrocarbon or mineral production, transit fees, international aid, or global investments. As a result, rentier theorists claim, such states are less reliant on taxation, are not so vulnerable to demands for 'no taxation without representation', and are in turn far less likely to develop strong democracy movements or democratic institutions. On the contrary, the theorists claim, such states assume an autonomy from and power over society, are essentially 'distributive' rather than 'productive', and thus become characterised not just by deepening authoritarianism, but also by patronage, clientelism, and the construction of powerful internal security apparatuses (for classic statements, see e.g. Beblawi and Luciani 1987). From this perspective, there is thus a natural correspondence between high hydrocarbon production and export dependence on the one hand, and illiberal politics on the other. The Middle East's supposedly exceptional development path can be summed up in a single three-letter word: oil.

The attractiveness of this theory lies in its parsimony and superficial empirical plausibility. It provides an easy way of explaining, for instance, why the Gulf emirates have achieved such rapid economic development without political liberalisation, and have become home to such striking juxtapositions of modernity and tradition. Simultaneously, it also functions as the exception that proves the rule, in effect assuming and affirming the myth of unilinear development discussed above. Yet for all this, rentier state accounts of Middle Eastern development are 
deeply flawed. Rent-dependent states, including oil-producing ones, have always been characterised by a wide variety of political systems and forms, from the liberal democratic (e.g. Norway), to the centralised authoritarian (e.g. the Gulf emirates), through to the chaotically and violently decentralised (e.g. Nigeria). And context-specific historical and political factors explain these differences, not the simple formula of access to external rents - just as also applies in relation to the 'developmental state' (see e.g. Kohli 2004).

Moreover, as developments since 2011 have shown, the supposed authoritarian 'resilience' (Anderson 1991) of the Middle East's rentier states is a myth. Libya, a classical authoritarian rentier state, has collapsed into civil war with little prospect of reconsolidation. Neighbouring Egypt, by contrast, has displayed striking 'authoritarian resilience' - indeed, an authoritarian return - despite its much lighter dependence on external rents. The resilience of Bahsar al-Assad's regime in Syria owes little to oil production, because most of this has been lost to the opposition. And the Middle East region as a whole, which for so long was characterised by retarded political development, but nonetheless regime durability and 'stability', is clearly no longer thus. The reason is clear: Middle Eastern states are not following a single or set development path, not even one that is determined by hydrocarbon resources (Beilin 2012).

\section{Myth number 4: that fragile statehood is the main institutional cause of violence}

The institutional corollary of the thesis that low development causes violent conflict is the claim that weak, failed or fragile statehood does too. The United Kingdom (UK)'s first National Security Strategy summed up this view well:

In the past, most violent conflicts and significant threats to global security came from strong states. Currently, most of the major threats and risks emanate from failed or fragile states. A failed state is one whose government is not effective or legitimate enough to maintain the rule of law, protect itself, its citizens or its borders, or provide the most basic services. A fragile state is one in which those problems are likely to arise (UK Cabinet Office 2008: 14).

Although the term 'failed state' has since fallen out of favour, the concept of 'fragile state', which is now preferred, does not constitute a significant departure from it - as the above quote makes clear. Today, state 'fragility' is understood as the central institutional conflict-development problem, and state 'resilience', its opposite, as the solution; but both are essentially understood as being about (actual or potential) state weakness.

Putting to one side the fact that, historically in the Middle East, the concept of 'resilience' has been applied to many authoritarian rentier states that have imploded; and putting aside also the frequent circularity of fragile state reasoning - fragile statehood contributes to violence, and we know which states are fragile because they are home to high levels of violence - the broader problem with the focus on weak or 
fragile states is that it is utterly inattentive to, and obscures, the abiding centrality of state actions and state power in practising, facilitating and otherwise causing political violence. The fragile state thesis boils down, in essence, to a claim that deficits of state capacity, legitimacy and authority, and the absence of the state in 'ungoverned spaces', underpin internal violence. But such deficits are typically accompanied by, and a consequence of, the powerful presence of state and state-backed forces, and their preparation for and resort to violence. In countries from Colombia to Sri Lanka to Sudan, it is not simply the weakness or fragility of the state that has been the problem, but the combination of internal legitimacy deficits (and not nationwide: only within certain regions, or among certain groups) and state militarism and repression (Stavrianakis and Selby 2013). Geopolitical dynamics - state-on-state diplomatic and economic support, plus the training and arming of state and paramilitary forces - are of course a key element in this. So far, so obvious. Indeed, the only thing that is surprising here is that contemporary conflict-security discourse, obsessed as it is with state 'weakness' and 'fragility', continues to be so blind to these issues.

Nowhere illustrates this better than the contemporary Middle East, where the post-2011 upsurge in political violence has been state, military (formal and informal) and geopolitically dominated. Here we must mention: the violent repression of the initial Arab Spring uprisings by military, security and police forces in most of the region's states; the overthrow of democratically elected regimes; the aerial bombing and mass displacement of populations not only in Syria, but also in Gaza, Iraq, Libya, Turkey and Yemen; renewed regional geopolitical machinations (which have involved, for instance, the Saudi state waging war directly in Yemen, while fighting local proxies in Syria and supporting the overthrow of the Muslim Brotherhood government in Egypt, all as part of its struggle for regional hegemony with Iran; and Turkey facilitating the rise of Islamic State (IS), while waging war against its own Kurdish population and using its Syrian refugees as a bargaining chip with Europe (Reuters 2016)); and, for all its supposed 'anti-interventionism', the West's wide-ranging military involvement in the region, as indicated by the fact that the US currently has military forces based in at least ten Middle Eastern states (see e.g. Heritage Foundation 2015: 103-4, whose list of eight does not include Israel and Turkey), and that the UK continues to arm the region's states, contravening the 2014 Arms Trade Treaty (Wintour 2014). It is hard but to conclude, given all this, that regional and international state actions and state power are the central motor of political violence in the contemporary Middle East. Yet no one would guess this from the language of state fragility.

\section{Myth number 5: that environmental scarcities are an increasingly important contributor to conflict}

A further recurring if secondary theme in contemporary conflictdevelopment thinking is the belief that environmental pressures are an increasingly important backdrop and contributor to conflict. Population growth, combined with rising consumer demand and the ceaseless intensification of resource exploitation, is without doubt 
placing growing pressures on land, water and other 'ecosystem services'; and for many, the inevitable upshot of this is mounting societal and international competition over scarce resources, increasing vulnerability to environmental shocks, and in turn proliferating impacts on livelihoods and stability. Global anthropogenic climate change is widely identified as an additional concern, one that will - or may already be be acting as a 'threat multiplier' to conflict in some of the most unstable parts of the world (CNA Military Advisory Board 2007). This thesis, far from marginal, has found its way into the national security strategies and development policies of most Western states, and United Nations (UN) bodies have widely adopted it too (see e.g. Selby and Hoffmann 2014b). Moreover, it is invoked more than anywhere else in relation to the Middle East, and to Syria in particular. The Syrian civil war, so the story goes, was in part sparked off by a severe climate change-induced drought that caused mass internal displacement, growing pressures on host communities, and in turn political protests, repression and war (Femia and Werrell 2012; Kelley et al. 2015). For its proponents, Syria is only the most conspicuous example of a broader trend and offers a glimpse of what is to come as the planet steadily warms.

Again, there is without doubt much superficial plausibility to this thesis, buttressed as it is by fears about the very sustainability - the resilience of our resource- and energy-intensive global hydrocarbon civilisation. And yet, it has shortcomings. For one, there is no consistent or reliable evidence of environmental pressures and shocks significantly contributing to any recent mass political violence. Quantitative studies are deeply divided on the issue, and their findings - whether positive or negative are in any case mostly statistical artefacts (Selby 2014). The 2003-5 war in Darfur, which was described as the 'first climate change war' (Mjøs 2007; Mazo 2010: 73-86), was, it is now widely acknowledge, nothing of the sort (Selby and Hoffmann 2014a). And the evidence that climate change, drought and ensuing migration played a significant contributory role in Syria's civil war is frankly derisory: among other problems, there is no evidence at all that drought migrants were either heavily involved in, or were targets of, any of Syria's early protests (Selby and Hulme 2015).

Such case evidence aside, there are broader reasons why environmental pressures do not inexorably translate into or exacerbate conflicts. Local environmental resource 'carrying capacities' are not set by nature alone, but also by technology and society, with new understandings and new technical interventions repeatedly making new resources available (in relation to water, for example: from far-away surface sources, to groundwater, to recycled wastewater, to the sea). And environmental resources are, in economic and political terms, of generally declining relative importance. Land and water, for example, are used above all for agriculture; and the relative decline in the economic and political value of agriculture, as shown by its generally declining contribution to GDP and employment, and the increasingly urban bases of political regimes, means that the economic and political value of water is in turn declining (Selby 2005). Such countertendencies make environmental conflicts less likely, not more. 


\section{Myth number 6: that countries need to pass a number of milestones on a democratisation pathway}

The twists and turns of political transformation in Arab countries where revolts have occurred, such as Egypt and Tunisia, profoundly contest Western theories of democratisation. Many of the earlier theories assumed that countries emerging from authoritarian regimes needed to achieve a number of milestones to make the bridge from democratic transition to democratic consolidation (Rustow 1970). Many more recent studies suggest the contrary, however. For instance, Carothers' study of twentieth-century regime changes in seven regions of the world contests a series of assumptions about democratic transitions: that regime change necessarily shifts towards democracy; that democracy evolves through phases (from breakthrough to transition to consolidation); that elections are of determinative importance; that elite pacts are crucial to the arrival of new governance strategies; and that democracy- and state-building are mutually re-enforcing endeavours (Carothers 2002). Carothers suggests that countries typically assume political pathways and outcomes that are in the 'grey zones', involving all kinds of configurations of power that do not fit into pre-conceived democracy-promoting models.

Yet since 2011, faith in a linear pathway to democracy has continued to inform the policy prescriptions of most Western academics and policymakers. This was very much captured in the language of 'democratic transition' that characterised Western policy debates in 2011-13. In practice, this concern with 'a transition to democracy' became heavily associated with processes of holding and monitoring elections. Rather than seeing elections as one of many important proxies for the people's expression of voice, they became a synonym for democracy itself. For example, after the Muslim Brotherhood came to power in Egypt in 2012, citizens continued to express their voice through - among other means - demonstrations, marches and sit-ins to protest against economic hardship, monopolisation of political power, and the absence of personal and public safety.

Concurrently, the revolutionary forces never stopped proclaiming that 'the revolution is ongoing'. Ali Bakr shows in his article in this IDS Bulletin that the Muslim Brotherhood's assumption of power did not herald the adoption of progressive pro-social justice policies in Egypt, a finding that parallels Dalacoura (2016)'s comparison of the Muslim Brotherhood in Egypt and Al-Nahda's policies in Tunisia. Rezk captures the sentiment in 2012, showing how citizens' high aspirations that the government that assumed power after the ousting of president Hosni Mubarak (1981-2011) would be pro-poor and pro-youth were disappointed. Rezk argues that the replacement of Mubarak's crony entourage with yet another business elite, this time affiliated to the Brotherhood, plus the governance challenges that the new leadership faced, led to widespread dissillusionment and fuelled the angry protests that resulted in the collapse of Mohamed Morsi (2012-13)'s government in June 2013. 
Yet much of the Western academic and policy analysis from that period focused on elections as the appropriate pathway by which revolutionaries should endeavour to achieve their goals, citizens express their voice, and elites challenge the new configuration of power (Carothers 2013; Lynch 2012; Ottaway 2013; Stepan 2012). Democracy, in such a narrow, linear framing, was reduced, in the eyes of one Egyptian analyst, to a 'boxocracy' (Ezzat 2013). The outcome of framing democracy from a Western perspective produced new disconnects in understanding why people joined a mass uprising in 2013 in even larger numbers than in 2011.

A new round of legislative elections took place in Egypt in December 2015-early 2016, and once again the ballot box proved to be redundant in capturing the pulse of the citizenry in terms of the changing political preferences of populations across time. Ten years earlier, former US secretary of state Condoleezza Rice praised the 'democratic transition' in Iraq where citizens had participated in three national elections (CNN 2005). Elections were once again used as a proxy for democracy, even when they entailed high levels of violence and produced highly exclusionary outcomes for parts of the citizenry. Clearly the privileging of elections as a proxy for citizen voice can be dangerous and disconnected from contexts in which people are resorting to a myriad of ways of expressing their agency, both violent and non-violent. Whatever the political predicament of the Syrian civil war, let us hope that building an inclusive, stable political order is not reduced once more to confusing a 'ballotocracy' for democracy.

\section{Myth number 7: that more humanitarian aid will contain the Syrian refugee crisis}

At the top of Amnesty International's eight-point plan to address the global refugee situation is 'continuous, sufficient and predictable funding for refugee crises'. In Amnesty's view 'all humanitarian appeals for refugee crises must be fully funded, in addition to providing meaningful financial support to countries that host large numbers of refugees to help them provide services to refugees and their host communities' (Amnesty International 2015). A major conference held in London in February 2016, hosted by the UK government, urged wealthy countries to commit to increase aid for the Syrian humanitarian crisis (see Deane, this IDS Bulletin). It is unquestionnable that funding is urgently needed to address humanitarian needs, but ultimately there is a need to understand that the humanitarian regime is deeply flawed in fundamental ways.

How geopolitical interests systematically trump the wellbeing of civilians lies at the heart of the redundancy and sometimes harm associated with humanitarian policy. Since the beginning of the Syrian civil war, Western actors have time and again prioritised geostrategic interest over humanitarian policy, even when humanitarian disasters could have been mitigated or addressed in a way that would have benefitted the populations in question the most. Former president of Finland and 
Nobel Peace Prize winner Martti Ahtisaari argued that the Western powers failed to engage with a Russian proposal in 2012 for Assad step aside as part of a peace deal because they were so convinced that the Syrian president was about to be toppled. At that time, around 7,500 people had been killed in the Syrian conflict; by early 2016, the number was more than 470,000 (Borger and Inzaurralde 2015; Barnard 2016).

A high-level official for a multilateral agency that was managing one part of the relief operation in Syria at the time said that in 2012 he had proposed to Western powers that the humanitarian aid effort should focus on resettling Syrians who were fleeing the war zone in parts of the country where there was no fighting. He explained that investing in income-generating opportunities and expanding the capacity of local education and health systems in the non-war zones would have been far less traumatic for them than to become refugees outside their country. However, he said that the Western donors would hear none of it because they feared that investing in regime-held territories would strengthen Assad; and besides, they were confident that it was only a matter of months before he was gone.

The Syrian regime has unquestionably committed atrocities that amount to crimes against humanity; however, the point here is that the execution of a foreign policy premised on Assad's overthrow rather than a political settlement has not only led to a serious threat to the territorial integrity of the country - parts of which are under IS control - but also the escalation of a humanitarian disaster unprecedented since the Second World War. At a civil society conference that was held in parallel to the London conference, the director of advocacy group The Syria Campaign, James Sadri, said:

Donors are being asked to give [US] \$9bn and not a penny of that will reach the most vulnerable people in the besieged areas. That's the elephant in the room. If the biggest UN aid operation in history is happening while people are starving to death something is fundamentally wrong (Wintour and Black 2016).

The problem is not only that geostrategic priorities trump a peoplecentered policy, or that the humanitarian regime needs to be well funded, but that it also needs to be fundamentally reconfigured. In this IDS Bulletin, Dawn Chatty argues that in establishng refugee camps and channelling assistance through these the humanitarian regime only reaches a minority of displaced and dispossesed people, a situation that the UN has acknowledged in its estimates that 'over 70 per cent of the Syrian refugee flow across international borders is self-settling in cities, towns and villages where they have long-established social networks. Many refuse to register as refugees and so are "invisible" to aid agencies.' Chatty also notes that in the neighbouring countries that are hosting the majority of Syrian refugees - Jordan, Lebanon and Turkey - the message that participants in the research conveyed was clear: selfsettlement was far better than encampment. 
In many of these surrounding countries, some Syrian families have social networks that they can rely on to access income-generating activities to survive temporarily until they can return home. The policy of containment in camps that the UN High Commissioner for Refugees (UNHCR) manages in Jordan has led to the increased impoverishment of Syrians as it has deprived them of opportunites to earn a living or rely on their networks outside the camps. The refugee containment process was so unpopular with refugees, notes Chatty, that UNHCR early on resorted to separating extended families to minimise the prospects of protest, waiting until it was dark to allocate tents to them in different parts the camp.

The application of humanitarian blueprints in Syria based on experiences from other parts of the world has rendered aspects of the aid administration entirely disconnected from the lived realities of the refugees. The Syrians fleeing the crisis are part of a complex ethnoreligious, middle-income region of the world, yet the humanitarian operations have assumed they have the same background and needs as, for example, refugees in sub-Saharan Africa, whose social and economic profile is very different. Chatty argues that if the humanitarian regime had listened to the priority needs that dispossessed Syrians expressed, it could have adopted measures that made a meaningful difference. Undoubtedly some humanitarian actors have listened, but Chatty's analysis shows that where Western humanitarian assistance programmes were set up as they were in Jordan and Lebanon, they were disconnected from Syrians' needs and priorities - which is not surprising, because they were rarely ever consulted.

Shelley Deane's article in this IDS Bulletin on Syria's lost generation notes that the international humanitarian regime has failed to address the educational needs of the 5.4 million children inside Syria, of whom 2.1 million are not in school; and, '[of] the 1.4 million Syrian refugee children in Syria's neighbouring host states 50 per cent are not in school.' Deane identifies several factors that have contributed to this, such as state incapacity to absorb large numbers in host countries, boys dropping out of school (to work to earn a living) and girls also (to marry, relieving their families of an additional mouth to feed and to protect the girls' honour by having a second family that is concerned for their safety and security).

Generations are losing out on schooling, in stark contrast to the pre-war education system where 93 per cent of children in Syria were enrolled in schools. Informal educational opportunities and standardised curricula, language and leadership training are all needed to address the educational gap. However, educational services are piecemeal, sometimes inaccessible and often ill fitted to the needs of Syrian children. Moreover, international support for young people to enrol in higher education is absent, because it is deemed a low priority for humanitarian aid interventions, which focus more on what they perceive as the 'basics'. 


\section{Myth number 8: that, following the Arab Spring, people's agency has been defeated}

Against the backdrop of civil wars (Libya and Syria), IS occupation (Iraq, Syria), threat of famine (Yemen), severe encroachments on freedoms (Egypt, Turkey), the ongoing Arab-Israeli conflict (Palestine), and strong ripple effects on neighbouring countries (Lebanon), the mood of optimism around the 2011 'Arab awakening' has waned. In Western media, academia and policy circles, talk of a perpetual 'Arab Winter' (The Economist 2016; Hinnebusch 2012) has replaced the Arab Spring rhetoric. As Jessica Winegar has written in a powerful and reflective piece, the Western media currently portrays the region as 'just one miserable homogeneous place of violence, terror, religious fanaticism and authoritarianism'. And yet, she adds, 'what is missing in these portrayals is the fact that in an area of the world with 350 million individuals spread across nearly 25 countries, there is not one story. In fact, there are positive events everywhere' (Winegar 2016).

A number of complex reasons account for the absence of nuanced representations of the multiple forms of positive agency that Winegar speaks of, and the implications are grave. The negation of the agency of the multitude has a serious bearing on our understanding of pathways of change, the pulse of the citizenry, and the dynamism and myriad faces of resistance and defiance. Underpinning the negation of some forms of citizen agency is a narrow focus only on those forms of activism that directly contest the authority of regimes and employ accepted modalities of resistance (especially movements that press for democracy by holding protests and marches).

In contrast, when citizens repeatedly organise around issues of economic wellbeing and personal safety by blocking roads, refusing to leave government premises until their grievances are taken seriously or standing silently in front of their syndicates and unions, holding placards with their demands, these forms of contentious politics are often dismissed as irrelevant to processes of political transformation. For example, before the January 2011 uprising in Egypt, much of the literature spoke of the inertia that characterised Egyptian political culture - despite being at a time when people were publicly and collectively defying norms of compliance and subservience (Tadros 2012; Ali 2012). If we examine the plurality of expressions of dissent from Syrians' protests in the refugee camps in Atimeh on the Syria-Turkey border, to secondary students protesting over educational policies in Egypt, we find forms of political engagement that are fluid, dynamic and may have unexpected ripple effects.

A second important factor contributing to the negation of citizen expressions is normative: when citizens protest against regimes that Western democracy 'experts' and academics have deemed to be bad, their agency is celebrated; whereas when citizens rise up against regimes that they consider to be illegitimate, but which in the eyes of the West are 'democratic', then the citizens are either condemned or made 
invisible. Irrespective of the outcome of the uprising of June 2013 against the Egyptian regime, people had in effect gone out in the hope that, by bringing down a president who had failed to deliver on his promises, they would bring an end to their deteriorating circumstances. Clearly, the political configuration of power that emerged was hardly conducive to the achievement of the 2011 January uprising's calls for 'bread, freedom and social justice' - and so much less so the highly authoritarian regime that holds power now.

However, it was a people's uprising that reinforced Egyptians' belief that they need not acquiesce to a ruler they did not want. Yet because the 2013 uprising occurred against a ruler who came to office through procedural democracy (elections), the way that many represented the revolt against the Muslim Brotherhood emphasised that it was antidemocratic and had destroyed any prospect of genuine democracy (Fadel 2014). The same normative judgement is at work when Western experts criticise Egyptians for not pursuing the path prescribed for them; for example, in the claim that 'the problem with Egypt's revolution is not that it is eating its children; instead many of its children are devouring it' (Brown 2014).

A distinct but related myth is that the conspiracy to bring down a democratically elected regime that heralded a unique Islamist democratic experiment in Egypt has ignited Islamist jihadi activism in the region. Such a myth is premised on the notion that by Islamists participating in and gaining victory at the ballot box, there was a genuine opportunity for democratising radicals who would have faith in the system and abandon violence. According to this myth, the sudden overthrow of the Morsi regime catalysed Islamists to pick up arms. Ali Bakr's article in this IDS Bulletin points to the increase in violence in 2013 after the demise of Morsi's government; however, its detailed mapping of radical Islamist activism shows that movements began to flourish as far back as 2011. Following the Arab revolts in 2011, against the backdrop of relaxed border controls, the breakdown of the security apparatus and increased political opportunities for activism, radical Islamist movements began to build up their recruits and acquire weapons. In other words, it was not in reaction to the downfall of the Morsi regime that jihadists became active; it was at that critical juncture when society and politics were being re-ordered that radical Islamists sought to instate their own rule and governance.

At a historical moment when counter-revolutionary forces wish to make people's uprisings invisible, it is critically important to resist defeatist narratives that deny the power of the multitude to challenge political orders. The notion of 'prefiguration' is important here. Grounded in anarchist theory, prefiguration refers to 'a political action, practice, movement, moment or development in which certain political ideals are experimentally actualised, in the "here" and "now" (Van De Sande 2013: 23). Prefiguration offers a lens through which to resist counterrevolutionary narratives by deconstructing them but also by creating 
alternative ones. The case of Rojava is not without its weaknesses, problematics and inequalities; however, as Cemgil and Hoffmann describe in their article in this IDS Bulletin, it represents a case of experimentation with an alternative social, political and economic order that seeks to establish more participatory, egalitarian forms of governance. By emphasising the power of people's ability to challenge red lines, and to collectively engage in a common struggle of liberation, the idea of prefiguration can help us to 'recognise the value and significance of certain practices which when seen from a 'chessboardperspective' may not be deemed 'successful' or 'important' or significant at all' (ibid.: 238); in other words, one of appraising an action exclusively in terms of its ability to achieve an immediate desired reaction.

The value of prefiguration lies not only in challenging counterrevolutionary narratives, but also in challenging the internalisation of power, empowerment and powerlessness. When citizens see and experience the ability to bring down the status quo through mass mobilisation, and from that, recognise their own power, it fundamentally changes the way they engage with oppression. They may not necessarily always revolt through mass demonstrations and protests, but they can strategically choose means of resistance that allow them to transgress and defy red lines in significant ways.

Akram Alfy in this IDS Bulletin exposes ways that youth movements have tactically used violence in Egypt since the January 25, 2011 uprising to challenge the status quo that has been unresponsive to their demands for political and economic reform. He argues that it is not so much the existence of a youth bulge that is a predictor of violent expressions of agency, but a constellation of factors, which include the very high level of education that characterises their profile, that is important. The structural problem that pre-dates the uprising persists to this day: a youth cohort educated to tertiary level is unable to find adequate employment in a context where few channels exist by which to hold the government to account. They are sure to continue to create their own channels to express grievances, even if they do not necessarily resort to violence in the future.

Authoritarianism may reproduce itself through the reconfiguration of discourses and practices that instil terror and oppression. However, when people revolt and bring down political orders, something happens to them and this 'something' needs to be kept alive because it can serve as a perpetual reservoir of resistance. Without romanticising people's power, there is ultimately a need to challenge the myth that people have reverted to complacency, apathy and apolitical engagement, just because they do not do politics the way Western democracy experts expect them to. 


\section{References}

Ali, Khaled (2012) 'Precursors of the Egyptian Revolution' in

M. Tadros (ed.), 'The Pulse of Egypt's Revolt', IDS Bulletin 43.1: 16-25, http://bulletin.ids.ac.uk/idsbo/article/view/340 (accessed 21 March 2016)

Allouche, Jeremy and Lind, Jeremy (2013) A New Deal: Development and Security in a Changing World, Brighton: IDS

Amnesty International (2015) Catastrophic Moral Failure as Rich Countries Leave Millions of Refugees to Cruel and Uncertain Fates, 12 October, www.amnesty.org/en/latest/news/2015/10/catastrophic-moralfailure-as-millions-of-refugees-left-to-cruel-and-uncertain-fates / (accessed 21 March 2016)

Anderson, Lisa (1991) 'Absolutism and the Resilience of Monarchy in the Middle East', Political Science Quarterly 106.1: 1-15

Barnard, Anne (2016) 'Death Toll from War in Syria Now 470,000, Group Finds', New York Times, 12 February, www.nytimes.com/2016/ 02/12/world/middleeast/death-toll-from-war-in-syria-now-470000group

Beblawi, Hazem and Luciani, Giacomo (1987) The Rentier State: Essays in the Political Economy of Arab Countries, London: Croon Helm

Beilin, Eva (2012) 'Reconsidering the Robustness of Authoritarianism in the Middle East: Lessons for the Arab Spring', Comparative Politics 44.2: $127-49$

Berger, Peter (1999) The Desecularisation of the World, Washington DC: Ethics and Public Policy Center

Borger, Julian and Inzaurralde, Bastien (2015) 'The West Ignored the Russian Offer in 2012 to have Syria's Assad Step Aside', The Guardian, 15 September, www.theguardian.com/world/2015/ sep/15/west-ignored-russian-offer-in-2012-to-have-syrias-assad-stepaside (accessed 22 March 2016)

Brown, Nathan (2014) 'Egypt has Replaced a Single Dictator with a Slew of Dictatorial Institutions', The New Republic, 26 January, https://newrepublic.com/article/116352/amr-hamzawy-emadshahin-arrests-show-egypts-new-dictatorship (accessed 22 March 2016)

Carothers, Thomas (2013) Egypt's Dismal Opposition, A Second Look, Carnegie Endowment for International Peace, 14 May, http:/ / carnegieendowment.org/2013/05/14/egypt-s-dismalopposition-second-look/g3cf (accessed 22 March 2016)

Carothers, Thomas (2002) 'The End of the Transition Paradigm', Journal of Democracy 13.1: 5-21

Chossudovsky, Michel (2016) The Destruction and Political Fragmentation of Iraq. Towards the Creation of a US Sponsored Islamic Caliphate, Global Research Center, 6 January, www.globalresearch.ca/the-destructionand-political-fragmentation-of-iraq-towards-the-creation-of-a-ussponsored-islamist-caliphate/5386998 (accessed 20 February 2016)

CNA Military Advisory Board (2007) National Security and the Threat of Climate Change, Alexandria: Center for Naval Analysis

Collier, Paul (2003) 'Civil War as Development in Reverse', in Paul Collier, V.L. Elliott, Håvard Hegre, Anke Hoeffler, Marta 
Reynal-Querol and Nicholas Sambanis (eds), Breaking the Conflict Trap: Civil War and Development Policy, Oxford: Oxford University Press: 13-32

Cramer, Chris (2006) Civil War is Not a Stupid Thing: Accounting for Violence in Developing Countries, London: Hurst

GNN (2005) World Leaders Praise Voter Courage, 30 January, http://edition.cnn.com/2005/WORLD/meast/01/30/iraq. internatreax/ (accessed 3 April 2016)

Dahi, Omar (2012) 'The Political Economy of the Egyptian and Arab Revolt', IDS Bulletin 43.1, http://bulletin.ids.ac.uk/idsbo/article/ view/343 (accessed 22 March 2016)

Dahi, Omar and Munif, Yasser (2011) 'Revolts in Syria: Tracking the Convergence between Authoritarianism and Neoliberalism', fournal of African and Asian Studies 47.4: 323-32

Dalacoura, Katerina (2016) 'Islamism and Neoliberalism in the Aftermath of the 2011 Arab Uprisings: The Freedom and Justice Party in Egypt and Nahda in Tunisia', in Akçalı (ed.), Neoliberal Governmentality and the Future of the State in the Middle East and North Africa, New York NY: Palgrave Macmillan: 61-84

The Economist (2016), 'The Arab Winter', 6 January, www.economist.com/ news/middle-east-and-africa/21685503-five-years-after-waveuprisings-arab-world-worse-ever (accessed 22 March 2016)

Ezzat, A. (2013) Revolution?' Coup d'etat? The Certain Thing is We Broke the Boxocracy, Jadaliyya, 13 July, www.jadaliyya.com/pages/index/12948/ revolution-coup-d $\% 25 \mathrm{E} 2 \% 2580 \% 2599 \% 25 \mathrm{C} 3 \% 25 \mathrm{~A} 9$ tat-thecertain-thing-is-we-bro (accessed 22 March 2016)

Fadel, Mohamed (2014) 'What Killed Egyptian Democracy?', Boston Review, 21 January, https://bostonreview.net/forum/mohammadfadel-what-killed-egyptian-democracy (accessed 22 March 2016)

Femia, Francesco and Werrell, Caitlin (2012) 'Syria: Climate Change, Drought and Social Unrest', Briefer 11, Washington DC: Center for Climate and Security

Friedman, Thomas (2005) The World is Flat: The Globalised World in the Twenty-first Century, London: Penguin

Friedman, Thomas (1999) The Lexus and the Olive Tree, London: HarperCollins Fukuyama, Francis (1992) The End of History and the Last Man, New York NY: Free Press

Heritage Foundation (2015) 2016 Index of US Military Strength, Washington DC: Heritage Foundation

Hinnebush, Raymond (2015) 'Arab Spring to Arab Winter: Explaining the Limits of Post-Uprising Democratization', special issue of Democratization 22.2

Hinnebusch, Raymond (2012) 'Syria: From "Authoritarian Upgrading" to Revolution?', International Affairs 88.1: 95-113

Kelley, Colin; Mohtadi, Shahrzad; Cane, Mark A.; Seager, Richard and Kushni, Yochanan (2015) 'Climate Change in the Fertile Crescent and Implications of the Recent Syrian Drought', Proceedings of the National Academy of Sciences 112.11: 3241-6

Kohli, Atul (2004) State Directed Development: Political Power and Industrialization in the Global Periphery, Cambridge: Cambridge University Press 
Lynch, M. (2012) 'Reflections on Egypt's Latest Crisis', Foreign Policy, 29 December, http://lynch.foreignpolicy.com/posts/2012/12/29/ reflections_on_egypts_latest_crisis?wp_login_redirect $=0$ (accessed 7 May 2013)

Macmillan, Steve (2014) Order Out of Chaos: The Global Elites Plan for a 'Middle Eastern Union, New Eastern Outlook, http://journal-neo.org/ 2014/08/18/order-out-of-chaos-the-global-elites-plan-for-a-middleeastern-union/ (accessed 22 March 2016)

Matin, Kamran (2013) Recasting Iranian Modernity, London: Routledge

Mazo, Jeffrey (2010) Climate Conflict: How Global Warming Threatens Security and What to Do About It, London: International Institute for Strategic Studies

Miller, L. (2012) How Does the Arab Spring Compare to Third Wave Transitions?, Democracy Digest, 18 July, www.demdigest.net/ blog/2012/07/how-does-arab-spring-compare-to-third-wavetransitions/ (accessed 7 May 2013)

Mitchell, Andrew (2010) 'Development in a Conflicted World', speech at Royal College of Defence Studies (16 September), www.gov.uk/ government/speeches/development-in-a-conflicted-world (accessed 22 March 2016)

Mjøs, Ole Danbolt (2007) Award Ceremony Speech by Chairman of the Nobel Peace Prize Committee (10 December), www.nobelprize.org/nobel_prizes/peace/laureates/2007/ presentation-speech.html (accessed 22 December 2015)

Moore, Barrington (1967) The Social Origins of Dictatorship and Democracy: Lord and Peasant in the Making of the Modern World, London: Penguin

Ottaway, Marina (2013) 'The Unfinished Egyptian Transition', The National Interest, 25 January, http:/ /nationalinterest.org/ commentary/egypts-immature-revolution-8013?page $=$ show (accessed 7 May 2013)

Peres, Shimon (1993) The New Middle East, New York NY: Holt Pettersson, Therése and Wallensteen, Peter (2015) 'Armed Conflicts, 1946-2014', Fournal of Peace Research 52.4: 536-50

Reuters (2016) Turkey's Erdogan Threatened to Flood Europe with Migrants, 8 February, www.reuters.com/article/us-europe-migrants-eu-turkeyidUSKGN0VH1R0 (accessed 5 April 2016)

Rostow, Walt (1960) The Stages of Economic Growth: A Non-Communist Manifesto, Cambridge: Cambridge University Press

Rustow, Dankwart (1970) 'Transitions to Democracy', Comparative Politics 2.3: 337-63

Selby, Jan (2014) 'Positivist Glimate Conflict Research: A Critique', Geopolitics 19.4: 829-56

Selby, Jan (2005) 'The Geopolitics of Water in the Middle East: Fantasies and Realities', Third World Quarterly 26.2: 329-49

Selby, Jan and Hoffmann, Clemens (2014a) 'Beyond Scarcity: Rethinking Water, Climate Change and Conflict in the Sudans', Global Environmental Change 29: 360-70

Selby, Jan and Hoffmann, Clemens (2014b) 'Rethinking Climate Change, Conflict and Security', Geopolitics 19.4: 747-56 
Stavrianakis, Anna and Selby, Jan (2013) 'Militarism and International Relations in the Twenty-first Century', in A. Stavrianakis and J. Selby (eds), Militarism and International Relations: Political Economy, Security, Theory, London: Routledge: 3-18

Stepan, Alfred (2012) The Recurrent Temptation to Abdicate to the Military in Egypt, Freedom House, 13 January, www.freedomhouse.org/blog/ two-perspectives-egypt's-transition (accessed 7 May 2013)

Tadros, Mariz (2012) 'The Pulse of Egypt's Revolt', IDS Bulletin 43.1, http://bulletin.ids.ac.uk/idsbo/article/view/454 (accessed 22 March 2016)

UK Cabinet Office (2008) The National Security Strategy of the United Kingdom: Security in an Interdependent World, London: HMSO

Van De Sande, M. (2013) 'The Prefigurative Politics of Tahrir Square - An Alternative Perspective on the 2011 Revolutions', Res Publica 19: 223-9, http://link.springer.com/article/10.1007\%2Fs1 1158013-9215-9\#page-1 (accessed 22 March 2016)

Winegar, Jessica (2016) Five Exciting Developments from Across the Middle East in 2015, Middle East Report Online, 6 January, www.merip.org/ newspaper_opeds/oped010616 (accessed 22 March 2016)

Wintour, Patrick (2014) 'Ban Ki-moon Adds to Pressure on UK to Stop Arms Sales to Saudis', The Guardian, 5 February

Wintour, Patrick and Black, Ian (2016) 'David Cameron Calls for Billions More in International Aid for Syrian Refugees', The Guardian, 3 February, www.theguardian.com/world/2016/feb/03/ david-cameron-calls-for-billions-more-in-international-aid-for-syrianrefugees (accessed 22 March 2016) 